\title{
Ethnic humour in a multicultural society Lenka Gogová
}

Dr Lenka Gogová teaches foreign languages at the Institute of Language Competences at Prešov University in Prešov. In her research, she specializes in humour and its functions in different cultural environments. She primarily focuses on ethnic humour, which she studies and analyses from several theoretical aspects and perspectives - the psychological, sociological, linguistic and semiotic. For several years, she has successfully cooperated with the Institute of Media Studies on various projects aimed at mass culture and popular culture.

\begin{abstract}
:
The coexistence of different cultures in specific pluralistic settings not only has positive but also negative impacts. Besides exchanging cultural contents within a multicultural environment, societies use humour as a form of social interaction, which reinforces cultural interrelationships as well as ethnical differences. However, humour differs from culture to culture and from individual to individual. On the one hand, it develops social cohesion, fosters positive relations and increases the self-identification of the individual in relation to other ethnic groups, but on the other hand, it functions as an acceptable and tolerated form of aggression in a particular society. The bipolar character of humour stems from its status and functions. It serves both as a social unifier and a social separator. The most common paradigms of humour in social discourse are ethnic jokes or cartoons that are often built on fixed ethnic/racial stereotypes leading to social categorization but also to fast and correct decoding of semantic information by an audience. Ethnic jokes are social thermometers, recording and measuring the level of sensitivity towards specific cultural groups. The main aim of this paper is to introduce ethnic humour and its key functions in the context of ongoing cultural interactions and changes.
\end{abstract}

Humour as a form of communication and social interaction is a "universal human trait" (Raskin, 1985, p. 2) and an integral part of all human societies. Martin defines humour as "a type of mental play involving a light-hearted, non-serious attitude toward ideas and events" (Martin, 2007, p. 1). Thanks to its ambiguous nature, on the one hand humour can be universal, but also culture-specific on the other hand. As a social phenomenon it often deals with general themes or current events as well as universals and cultural specificities characteristic of particular societies. Moreover, it reflects the mentality of members or the perception of the world outside. It is often retrospective, built on historical fundamentals (past experiences, 
historical events, stories etc.), which means that it can be understood only by the members of a particular cultural community. Its social character is also visible in Raskin's view that "the scope and degree of mutual understanding in humour varies directly with the degree to which the participants share their social backgrounds" (Raskin, 1985, p. 16). If percipients are not familiar with the social and cultural environments presented in the humorous discourse, they will not decode the semantic information correctly, which may result in an absence of the desired effect. Laughter and a good mood are dominant indicators of understanding humour correctly and a subsequent achievement of the perlocutionary speech act.

We can perceive humour as a multi-perspective research subject whose versatility and interconnection of different scientific studies has become a central core for numerous theories. Throughout history, philosophers and scholars have tried to introduce various attempts to form a universal and satisfactory definition of this phenomenon as well as to explain how humour originates and what mental processes participate in its creation. All the partial definitional approaches were finally sorted into three mega theories: cognitive, social and psychoanalytical (see also Attardo 1994). Hostility theories focus on various disparagement strategies, e.g. aggression (Rapp 1951; Gruner 1997); Incongruity-Resolution processes (Suls 1972; Shultz 1976); and Release (or Relief) theories contain arousal-relief mechanisms (Freud 1905). These leading theories are often presented with slightly modified names (Raskin 1985). Humour is perceived as a cognitive experience that involves an internal redefining of social and cultural reality. Moreover, it results in a cheerful state of mind, of which laughter is a possible external demonstration (Apte 1985). In terms of semiotics, humour can be defined as a specific type of semiosis, where the sign is placed in relationship with other signs in unexpected or less probable associations (Rusnák 2002). This sign process achieves the nature of communication and social function within a specific community.

The first attempt to develop a theory of laughter is dated to the fourth century B.C., when the ancient Greek philosopher Plato tried to explain the causes of amusement and reasons associated with humour creation. In the dialogue Philebus (1975), Plato explains the essence of humour through a feeling of superiority while observing the weakness or misfortune of other people (who might be powerless). From his perspective, ridiculousness is in its main aspect a kind of evil or vice which is in fact self-ignorance: it means that we laugh at the people who think that they are wealthier, taller and better looking than they are or think that they possess better physical qualities. According to Plato (1975), amusement or laughter are a kind of malice or an emotion contrary to rationality and are morally objectionable. Based on Plato's philosophy, laughter was seen as one of the aspects of ugliness (as a negative feeling 
towards the speaker of the joke) as well as pleasure (the act of laughing), but was not accepted in society (Attardo 1994). Besides Plato, many other philosophers consider humour and laughter to be a negative demonstration in relation to the object of the joke as being inferior. Similarly, Aristotle defines comedy as "an imitation of people who are worse than the average, [...] the ridiculous [...] is a species of the ugly" (Aristotle in Morreall, 1987, p. 14). He introduces laughter as an indicator of scorn and wit as learned insolence. He distinguishes between uneducated and educated laughter; whereas educated laughter might be used as a way of social control and stimulation of the soul. Moreover, T. Hobbes (1982) talks about humour as something selfish and egoistic based on a sudden feeling of superiority. In Leviathan (originally published in 1651), he talks about "sudden glory" as "the passion which makes these Grimaces called laughter; and which is caused either by some sudden act of their own that pleases them, or by the apprehension of some deformed thing in another, by comparison whereof they suddenly applaud themselves" (Hobbes 1982).

It is important to note that the early perception and understanding of humour had a negative character rather than positive one. For example, in ancient Greece humour was not a part of everyday life. It was only acceptable during annual festivals and celebrations in honour of the god Dionysus (god of the grape harvest, ritual madness and fertility) with many theatrical performances of tragedies and later comedies. Therefore, laughter at failures and defects of others was considered a sign of cowardice and degradation which could not be naturally tolerated or accepted within society.

Gruner in his work The Game of Humor: A Comprehensive Theory of Why we Laugh, published in 1997, completes superiority theory with two key aspects. Besides the fact that every situation has a winner and a loser (the principle of superiority), it also requires an element of surprise and the presence of an incongruous element. Also Bergson (1993) considers the theory of superiority to be insufficient and introduces disharmony as a necessary component of humour. According to Berger (1998, p. 3) the term "incongruity" has various meanings - inconsistent, not harmonious, lacking propriety and not conforming. Kant (17241804) in the Critique of Judgement introduces the presence of something senseless as a priority condition for provoking laughter. Humour arises "from the sudden expectation of a strained expectation into nothing" (Kant, 1975, p. 142). Similarly, Schopenhauer (1998) outlines paradox, a contradiction between the concept (which is abstract) and the real object (which is perceptive), as the primary initiator of laughter. The phenomenon of laughter always signifies the sudden apprehension of an incongruity (Schopenhauer 1998). In fact, it is the 
juxtaposition of two or more improbable or unlikely elements within a specific humorous discourse.

Another dimension of the perception of humour is introduced by the theory of relief, which is based on the psychological and psychophysiological nature of human needs to relieve tension and energy. H. Spencer in the book On the Physiology of Laughter (1911) presents laughter as a release of natural impulses that are repressed. Moreover, Freud (2005) in his Jokes and Their Relation to the Unconscious (published in 1905) provides a closer look at three types of humour (the joke, the comic and the mimetic) where laughter as a specific means of catharsis helps to release nervous energy and thus lower stress hormones. He considers humour to be the highest defensive process converting inner negative feelings into feelings of satisfaction and pleasure.

The three major theories have become the basis for many other theories, such as the semantic script theory of humour (SSTH) created by Raskin (1985). It is among the most important linguistic theories focusing on verbal humour and its attributes. The theory is based on an analysis of the text of a joke; the concept of the theory is the notion of script. The term script means a frame/schema presenting semantic information about the object or event reflecting the structure of entities. The central hypothesis is based on the following condition: "The text is compatible, fully or in part, with two different scripts [...] the two scripts with which the text is compatible are opposite and overlap fully or in part on this text" (Raskin, 1985, p. 99) and subsequent resolution of incongruity in the final stage. The most frequent abstract binary oppositions used in jokes are: normal/abnormal, actual/non-actual and possible/impossible.

Based on linguistic theory, Attardo and Raskin (1991) have formed an extension to the previous theory, called the general theory of verbal humour (GTVH), which focuses not only on the semantic aspects of verbal humour but also on fields of linguistics such as pragmatics, textual linguistics and discourse analysis. They have developed a hierarchical system of six parameters called knowledge resources or, in other words, hypothetical sources of knowledge present in the cognitive representation and analysis of texts (Table 1).

\section{Table 1 "Knowledge resources"}

\begin{tabular}{|l|l|l|}
\hline PARAMETER & DEFINITION & EXAMPLE \\
\hline 1. Language (LA) & $\begin{array}{l}\text { verbalization of the } \\
\text { text/content of the joke: }\end{array}$ & $\begin{array}{l}\text { - based on semantic } \\
\text { ambiguity }\end{array}$ \\
\hline
\end{tabular}




\begin{tabular}{|c|c|c|}
\hline & $\begin{array}{l}\text { selection of linguistic } \\
\text { components, position of } \\
\text { functional components } \\
\text { (pronunciation, syntax, } \\
\text { vocabulary, etc.) }\end{array}$ & - punch line of the joke \\
\hline 2. Narrative Strategy (NS) & $\begin{array}{l}\text { narrative organization of } \\
\text { the text (genre or micro- } \\
\text { genre) }\end{array}$ & $\begin{array}{l}\text { - narrative, story } \\
\text { - riddle } \\
\text { - dialogue, conversation }\end{array}$ \\
\hline 3. Target (TA) & $\begin{array}{l}\text { humour targeted at } \\
\text { specific (social) } \\
\text { stereotypes (group, } \\
\text { individuality), mocking } \\
\text { of a certain social group } \\
\text { - feeling of superiority }\end{array}$ & $\begin{array}{l}\text { - humour targeted at } \\
\text { cultural and national } \\
\text { specificities (ethnicity, } \\
\text { religion, target-centred } \\
\text { e.g. mothers-in-law, etc.) } \\
\text { - humour emerging from } \\
\text { specific characteristics - } \\
\text { mostly negative (such as } \\
\text { ugliness, foolishness, } \\
\text { unskillfulness, etc.) }\end{array}$ \\
\hline 4. Situation (SI) & $\begin{array}{l}\text { implementation of } \\
\text { content components or } \\
\text { "props" into the } \\
\text { situation: characters, } \\
\text { acting, instruments, } \\
\text { environment, etc. }\end{array}$ & $\begin{array}{l}\text { - funny situation } \\
\text { appearing in a certain } \\
\text { point of the story }\end{array}$ \\
\hline 5. Script opposition (SO) & $\begin{array}{l}\text { the main condition for } \\
\text { establishment of the } \\
\text { humorous effect: } \\
\text { compatibility - script } \\
\text { opposition }\end{array}$ & $\begin{array}{l}\text { - two scripts that are } \\
\text { opposite - binary } \\
\text { oppositions }\end{array}$ \\
\hline $\begin{array}{l}\text { 6. Logical Mechanism } \\
\text { (LM) }\end{array}$ & $\begin{array}{l}\text { mechanisms connecting } \\
\text { two different scripts in } \\
\text { the text; in other words } \\
\text { "false logic" (resolution } \\
\text { of incongruity) }\end{array}$ & $\begin{array}{l}\text { - juxtaposition of entities } \\
\text { which are usually not } \\
\text { connected } \\
\text { - incongruity between two } \\
\text { entities }\end{array}$ \\
\hline
\end{tabular}

Plurality and diversity of cultures is often connected with not only self-awareness of cultural differences in relation to other social groups but also with the perception of one's own status within the group, based on a feeling of solidarity, friendship and cooperation. The social nature of humour can be reflected in its production. It is difficult or even impossible to enjoy 
humorous discourse in isolation, since laughter needs a kind of response (compare with Bergson 1993). The function of humour within a group takes two forms: 1. personal meaning of humour for an individual within a social group; 2. social roles of humour in a social group (Ziv 2010).

Ziv (1984) classifies the main functions of humour into the following five aspects:

1. Arising social taboos - humour serves as a regulator of social tension, which is often manifested in the sphere of taboo topics. For civilized societies it is necessary to repress or regulate themes that are associated with the natural needs of people such as sexual ones or any themes relating to various forms of aggression. Humour provides an adequate environment for airing impulses, resolving conflicts and establishing nonviolent control. It can be said that humour serves as a form of catharsis which helps transform negative feelings into pleasure and satisfaction.

2. Social criticism - points at the negative aspects in society. In this case humour helps to differentiate between acceptable and unacceptable social behaviour. Satire and irony/sarcasm (specific forms of humour) are used as appropriate instruments for criticizing societies, their political systems, norms, issues, objectives etc. Through satire and irony, political institutions as well as individuals that cause frustration and dissatisfaction are ridiculed. On the other hand, these forms of humour are also used to restore or promote social hierarchy and status and to achieve changes or a certain correction of errors within the society.

3. Consolidation of group membership - a symbol of social and cultural unity/integration and division. It is used as an essential means of excluding or accepting the individual by other group members. As Bergson points out: "Our laughter is always the laughter of a group" (Bergson, 1993, p. 3). It is necessary to place humorous discourse into human societies, since social functions and social meanings of humour can be established only in a natural social environment. Joking relationships created between two individuals with a certain social bond, "mark group identity and signal the inclusion or exclusion of a new individual" (Apte, 1985, p. 56) but also "manifest a consciousness of group identity or solidarity" (ibid., p. 66). In particular, similarities of the members of the same group are strengthened and maximized, but on the other hand differences are minimized. Within a group interaction an idioculture (a small group culture) is formed, which is defined as "a system of knowledge, beliefs, behaviours and customs shared by members of an interacting group to which members can refer and employ as the basis of further interaction. Members recognize that they share experiences, and these experiences can be referred to with the expectation that they will be understood by other members" (Fine, 1979, p. 734). Within the communication process, humour is an essential 
aspect of pragmatic (perlocutionary) aspects of the speech act. Correct understanding/decoding of humorous texts is accompanied by specific physiological expressions such as a grin, smile or laughter, which help to establish social cohesion.

4. Defence against fear and anxiety - another social function of humour is its defensive function against negative emotions. It is a form of controlling, suppressing and overcoming fear and worries, alleviating anxieties or releasing serious conversational themes. According to Martin, humour "has been adapted as a means of dealing with difficulties and hardships" (Martin, 2007, p. 20). It is very often used as an effective means of fighting against serious societal problems such as death, war, famine, disasters etc. In other words, humour helps people to cope with unpleasant and awkward situations; it turns problems into something humorous people can laugh at. The most commonly used form of humour, which is characterized by the abovementioned aspects, is black humour. We offer the following joke as an example:

A man wakes from a coma. His wife changes out of her black clothes and remarks irritably: "I really cannot depend on you in anything, can I?!"

5. Intellectual play - helps individuals to escape from unpleasant experiences and gain control over feelings connected to these experiences. The presence of playfulness is related to the momentary establishment of freedom and achievement of liberation. Although humour primarily involves cognitive processes, understanding the punchline of a joke also requires the mobilization of additional emotional processes based on past experiences as well as a degree of emotional involvement at the time of receiving the humour, arising from subjective moral principles or a momentary state of mind.

Anthropological approaches to the understanding of the term "ethnicity" as a social phenomenon have changed over the years. The initial perception of ethnicity was based on primordialist theories that consider ethnicity "the essence, the quality core", which may take the form of cultural signs (language, religion, values, norms), territorial characteristics (country, region, nationality) or biological traits (ancestors, race, tribe) (Bačová, 1996, pp. 2325). Ethnicity generally refers to a certain quality or affiliation based on hereditary as well as cultural considerations, as stated in Webster's Third New International Dictionary (Babcock, 1967, p. 781). A later approach to ethnicity, inspired by the formalist theory of ethnicity written by F. Barth (1969), is defined as situational or subjective. Here ethnicity is an aspect of intergroup social relations, a cultural distinction between "we and they" supported by 
cultural awareness (understanding cultural differences) and group identification, which is seen in members' perception of being different from members of other social groups. The term ethnicity involves the complexity of traits distinguishing a specific ethnic group from other ethnic groups, and social factors such as language, culture, ethnic awareness and ethnic name (i.e. ethnonym) are the most important components of ethnicity. On the other hand, Botík (1991, p. 21) states that ethnic groups can be defined as historically formed communities of people with a common origin, language and peculiarities in material as well as spiritual culture. Members of an ethnic group share the same culture (e.g. language or dialect), religion, customs, norms, behaviour and history. In contrast to the ethnic group, according to Kendall (1997, p. 231) "race is a category of people who have been singled out as inferior or superior, often on the basis of physical characteristics as skin colour, hair texture, and eye shape". Eriksen (2012, p. 27) emphasizes that race or ethnicity should be seen as related concepts, which partly overlap. However, as specific cultural aspects might be characteristic for certain racial groups, equally certain ethnic groups might possess specific physical characteristics, which results in confusion among anthropologists and leads to subsequent rejection of the very term "race".

The coexistence of different ethnic groups within a multicultural society brings a sense of community and group cohesion of the members of specific ethnic groups and a subsequent formation of shared images or fixed ideas/beliefs about other people/ethnicities known as "stereotypes". We differentiate between historical and national stereotypes. Historical stereotypes are a specific type of perception of people and the world, connecting history of mentalities, political history and history of intercultural contacts of the past. National stereotypes, as a common value system, help members of a society to enhance their coherence and perception of "our" society as different (Drabinová 1999). In the process of stereotyping (generalization of attributes made about members of a certain group), the person who belongs to a particular ethnic group is attributed with all the characteristics of that group. It is important to note that stereotypes not only evoke negative connotations but also positive or even neutral ones. Stereotypes about other people can be harmless if they carry an emotive load which is "neutral" and do not affect the interests of individuals (Giddens 1999). The negative view of stereotypes is closely associated with social categorization leading to prejudice or negative pre-judgment. Some authors consider stereotype and prejudice to be closely interrelated phenomena, with the same psychological nature (Nakonečný 1999); others think they are semantically equal terms. According to Allport (1954, p. 44) prejudice is "a model of enmity in interpersonal relations, aimed at a whole group or at its individual members; for its owner 
fulfils a specific irrational function". Stereotypes about other ethnicities (racist and ethnic stereotypes) arise from the perception of one's own cultural identity as something superior, which creates an essential basis for humour. Because humour is connected to cultural values and codes, joking relationships manifest social structures as well as cultural differences in exaggerated and funny ways.

To maintain equilibrium in a society and social hierarchy, humour is used as a doubleedged sword. On the one hand, it serves as a tool for improving interpersonal relationships within a group and supporting the positive psychological wellbeing of the individual. On the other hand, it can be used as a tolerated means of criticizing societies and expressing hostility against members of other social groups with different cultural identities, or even members of the same group who have violated established social norms or principles. From a personalitybased approach, humour can be divided into four humour styles (Kuiper et al. 2010):

1) Self-enhancing humour - manifests as an individual approach towards unpleasant situations perceived as funny and entertaining. It helps people to cope with difficulties and develop a positive attitude towards life. Self-enhancing humour is beneficial to psychological wellbeing, since it serves as a coping mechanism and is used to maintain self-esteem.

2) Affiliative humour - is used as an adaptive coping/surviving strategy, which involves confronting problems and difficulties in a positive way. Its aim is to reinforce intergroup relationships and create a pleasant atmosphere. People use this type of humour, e.g. nonhostile/innocent jokes, when they want to entertain and amuse other members of the group in a respectful way in order to improve social relationships and reduce tensions. Although it helps the individual to associate with other people and fortify self-identification within an ethnic group, affiliative humour strengthens social and cultural bonds as well.

3) Self-defeating humour - refers to the individual's personal imperfections and failures, which are a target of mockery. According to Klein and Kuiper (2006) people of a lower social status may use self-defeating humour as a form of regaining or improving peer relationships and social status.

4) Aggressive humour - is used to mock and tease other people with the aim of ridiculing or "hurting" them. It is built on the principle of superiority in relation to other cultural identities/groups. The most frequent forms of this type of hostile humour are irony and sarcasm used to satisfy aggressive feelings. Principally, aggressive humour forms the basis of ethnic jokes, which aim at a demonstration of dominance and superiority towards the "butt" of the joke. 
When talking about ethnic humour, it can be defined as a specific form of humour in which "perceived behaviours, customs, personality, or any other traits of a group or its members by virtue of their specific sociocultural identity" (Apte, 1987, p. 180) are analysed. According to Davies 'the term 'ethnic' tends to be used in a broad way about a group that sees itself and is seen by others as a people with a common cultural tradition, a real or imagined common descent, and a distinctive identity" (Davies, 1990, p. 1). The importance of ethnic identity can be seen in a multicultural society which is formed by two main types of group - the social majority group and the minority group. There exists a parallel between minority groups going through an acculturation process and the need for strong social cohesion, which helps them to maintain their own traditions, values and a sense of ethnic identity within a common territory. Each ethnic group is characterized by specific aspects such as geographic origin, ancestors, customs, language, race, tradition and physical attributes, which are also reflected in ethnic humour as the most frequently occurring topics (Apte 1985). Humour that is formed on the boundaries of two ethnic groups is mostly based on the principle of superiority, when one culture feels superior towards another ethnic group, different culture, language or tradition. Although ethnic jokes used in most societies mock different social or cultural attributes, the most common form of humour is based on a dichotomy - wise vs. stupid (Davies 1990). The first group includes ethnic jokes portraying the target group (often minority group) as "stupid, rude, uneducated, ignorant or dirty" in comparison with preferentially portraying the dominant local ethnic group as "wise, polite, educated, sophisticated or clean". The next type of ethnic joke is associated with the inability of the ethnic group to adapt to rapid technological progress in a society (due to lack of education, technical skills, social backwardness etc.) and which lives on the cultural or economic periphery with different cultural identities. Other important aspects are linguistic competence and religion, which form an integral part of most cultural groups. Ethnic groups living on the border of two linguistic territories, which try to speak the language of the majority group (e.g. immigrants), are characterized by verbal expression often containing elements of a second language or a specific dialect, which people, speaking the "pure" language, consider to be funny. Read the following joke:

A class of $5^{\text {th }}$ grade students was sitting studying English in class. The teacher asked, "Can anyone use the words, green, pink and yellow in a sentence?" The African-American child says, "The colours, green, pink and yellow are seen in the rainbow." An Irish child states, “My favourite colours are green, pink and 
yellow." The Mexican child says, "When the phone greens, I pink it up and say yellow."

The joke is an example of ethnic humour, which uses a minority ethnic group (in this case Hispanic/Latino Americans) as a target and the aspect of linguistic imperfection as a pivot in the narrative. The punchline is presented in the last sentence, whose verbal elements create the necessary incongruity based on stereotypical representation of Hispanic/Latino Americans. One of the typical and widely known stereotypes for Hispanics is that they are uneducated and unable to speak English fluently and correctly - even schoolchildren.

Humour is often used as an effective means of social influence, which reinforces not only order in society but also social hierarchy. The feeling of social cohesion is mostly manifested in relation to other members of the social group, in which a certain social status is formed. It also serves as a form of expressing emotions, moods, attitudes and opinions on a particular social issue, with the aim of developing in-group relationships, alleviate tension among members of the same group, enhance solidarity and self-identification. Furthermore, maladaptive humour styles such as hostile/offensive jokes, irony or sarcasm are often used to mock and ridicule members of other ethnic groups that are considered inferior.

\section{Works cited:}

Allport, G. W. 1954. The Nature of Prejudice. Cambridge, MA: Addison-Wesley.

Apte, M. L. 1985. Humor and Laughter: An Anthropological Approach. Ithaca, NY: Cornell University Press.

Apte, M. L. 1988. "Disciplinary boundaries in humorology: An anthropologist's ruminations." In: HUMOR: International Journal of Humor Research, vol. 1, no. 1, pp. 5-25.

Apte, M. L. 1987. Ethnic humor versus "sense of humor". In: American Behavioral Scientist, vol. 30 , no. 1 , pp. 27-41.

Aristotle -4th century. 1954. De arte poetica. English translation: "Poetics." In: Aristotle, Rhetoric. Poetics. New York: Random House, pp. 219-266.

Attardo, S. 1989. "A multiple-level analysis of jokes." Contributed section. In: Newsletter, HUMOR: International Journal of Humor Research, vol. 2, no. 4, pp. 438-439.

Attardo, S. 1994. Linguistic theories of humor: Humor research. Berlin: Mouton de Gruyter. Attardo, S. and Raskin V. 1991. "Script theory revis(it)ed: Joke similarity and joke representation model.” In: HUMOR: International Journal of Humor Research, vol. 4, no. 3-4, pp. 293-347.

Babcock G. P. 1967. Webster's Third New International Dictionary. Springfield, Mass.: G. \& C. Merriam.

Bačová, V. 1996. Etnická identita a historické zmeny. Štúdia obyvatel'ov vybraných obcí Slovenska. Bratislava: Veda.

Barth F. 1969. "Introduction." In: Ethnic Groups and Boundaries: The Social Organization of Cultural Difference, ed. F Barth, London: George Allen \& Unwin, pp. 9-38. 
Bergson, H. [1900]1993. Smích. Praha: Naše Vojsko.

Botík, J. 1991. "Etnicita ako základná kategória národopisnej vedy." In: Slovenský národopis, vol. 39, no. 1, pp. 18-25.

Davies, Ch. 1990. Ethnic Humor Around the World: A Comparative Analysis. Bloomington: Indiana University Press.

Davies, Ch. 1997. "The Newfoundland joke: A Canadian phenomenon viewed in a comparative international perspective." In: HUMOR: International Journal of Humor Research, vol. 10, no. 2, pp. 137-164.

Drabinová, D. 1999. "Etnické stereotypy a studující mládež.“ In: Gracová, B. Školní výuka dějepisu a překonávání stereotypních obrazů sousedních národi̊. Ostrava: Filozofická fakulta OU, pp. 5-49.

Eriksen, T. H. 2012. Etnicita a nacionalismus. Antropologické perspektivy. Praha: Slon.

Fine, G. A. 1987. With the boys: little league baseball and preadolescent culture. Chicago: University of Chicago Press.

Freud, S. 1905/1976. Jokes and Their Relation to the Unconscious. Harmondsworth: Penguin Books.

Freud, S. 2005. Vtip a jeho vztah k nevědomí. Praha: Šestá kniha.

Giddens, A. 1999. Sociologie. Praha: Argo.

Gruner, C. R. 1978. Understanding Laughter: The Workings of Wit and Humour. Chicago, IL: Nelson-Hall.

Gruner, C. R. 1997: The Game of Humour. A Comprehensive Theory of Why We Laugh. New Jersey: Transaction.

Hobbes, T. 1651 [1982], Leviathan, New York: Penguin.

Hobbes, T. 2009. Leviathan. Praha: Oikoymenh.

Kant, I. 1790. Kritik der Urtreilskraft. Berlin: Lagarde. English translation: Critique of Judgment. New York: Hafner, 1951.

Kant, I. 1975. Kritika soudnosti. Praha: Odeon.

Klein, D. N., \& Kuiper, N. A. 2006. "Humor styles, peer relationships, and bullying in middle childhood." In: HUMOR: International Journal of Humor Research, vol. 19, no. 4, pp. 4383404.

Kuiper, N. A., Grimshaw, M., Leite, C., \& Kirsh, G. 2004. "Humor is not always the best medicine: Specific components of sense of humor and psychological well-being." In: Humor: International Journal of Humor Research, vol. 17, no. 1/2, pp. 1/2135-168.

Kuiper, N. A., Kirsh, G. A., \& Leite, C. 2010. "Reactions to humorous comments and implicit theories of humor styles." In: Europe's Journal of Psychology, vol. 6, no. 3, pp. 3236-266.

Martin. R. A. 2007. The Psychology of Humor. An Integrative Approach. Amsterdam: Elsevier Academic Press.

McGhee, P. 1979. Humor. Its origin and development. San Francisco, CA: W.H. Freeman.

Monro, D. H. 1951. Argument of Laughter. Melbourne: Melbourne University Press.

Morreall, J. 1989. "Enjoying incongruity." In: HUMOR: International Journal of Humor Research, vol. 2, no. 1, pp. 1-18.

Morreall, J. 1991. "Humor and work." In: HUMOR: International Journal of Humor Research, vol. 4, no. 3-4, pp. 359-373.

Morreall, J. 1987. The Philosophy of Laughter and Humor. New York, SUNY.

Nakonečný, M. 1999. Sociální psychologie. Praha: Academia.

Plato 1975. Philebus. English translation: Oxford: Clarendon Press.

Rapp, A. 1951. The Origins of Wit and Humor. New York: Dutton.

Raskin, V. 1985. Semantic Mechanisms of Humor. Dordrecht: Reidel.

Rusnák, J. 2002. „Správy z druhej ruky“: Komunikačné stereotypy a ich fungovanie $v$ médiách. Prešov: Filozofická fakulta Prešovskej univerzity. 
Schopenhauer, A. 1998. Svět jako vůle a predstava II. Pelhřimov: Nová tiskárna Pelhřimov. Schultz, J. 1976. “A cognitive-developmental analysis of humour.” In: A. Chapman \& H. Foot (eds.) Humour and Laughter: Theory, Research and Applications. London: Wiley, pp. 11-36. Spencer, H., 1911. "On the Physiology of Laughter," Essays on Education, Etc., London: Dent.

Suls, J. 1972. "A two-stage model for the appreciation of jokes and acrtoons: An informationprocessing analysis." In: Goldstein \& McGhee (eds.) The Psychology of Humour. New York: Academic Press, pp. 81-100.

Websters, A. M. 1967. The New International Dictionary of English Language, G and C Memman Company Massachusset.

Ziv, A. 1984. Personality and sense of humor. New York: Springer Pub. Co.

Ziv, A. 2010. "The social function of humor in interpersonal relationships." In: Society, vol. 47, no.1, pp. 11-18.

\section{Lenka Gogová}

ÚJK CCKV Prešovská univerzita v Prešove

Ul. 17. novembra 15, 08001 Prešov

lenka.gogova@gmail.com 